\title{
HUBUNGAN WAKTU PENGGUNAAN LAPTOP DENGAN KELUHAN PENGLIHATAN PADA MAHASISWA FAKULTAS KEDOKTERAN UNIVERSITAS SAM RATULANGI
}

\author{
Grace P. Kurmasela \\ J. S. M. Saerang \\ Laya Rares \\ Kandidat Skripsi Bagian Ilmu Penyakit Mata Universitas Sam Ratulangi \\ Email: ms.kurmasela@yahoo.com
}

\begin{abstract}
Background: basically the eyes not compatible to observe intently monitor screen immediately even less take more time for that, because will caused ocular problems. But because of duty and general responsibility made somebody must to observe intently monitor screen into spesific time frame or can not count. Aim: The aim of this research is to know the related time of laptop use and ocular problems. Method: The method of this research is cross sectional with characteristic observation. And the problems to identify is happen by it self without intervention from researher. The samples is group 2011 students of Medical Faculty of Sam Ratulangi University amount to 100 peoples who take with random sampling. Results: The results indicate there is correlation break time of laptop use $(r=9,487, p<0,05)$ and duration time to feel ocular problems $(r=9,487, p<0,05)$ with ocular problems, whereas sexing $(r=3,841, p>0,05)$, story of laptop use $(r=5,991, p>0,05)$, and glasses user $(r=5,991, p>0,05)$ is not significantly related with ocular problems.
\end{abstract}

Conclusion: Time of laptop use is related with ocular problems.

Keywords: time of laptop use, ocular problems.

\begin{abstract}
Abstrak: Latar belakang: pada dasarnya mata tidak terlalu cocok untuk menatap layar monitor secara langsung apalagi berlama-lama karena akan menimbulkan keluhan penglihatan. Namun karena tuntutan tugas dan tanggung jawab mengharuskan seseorang menatap layar monitor dalam kurun waktu tertentu atau yang tidak ditentukan. Tujuan: Tujuan dari penelitian ini adalah untuk mengetahui hubungan waktu penggunaan laptop dengan keluhan penglihatan . Metode penelitian yang digunakan adalah cross sectional dengan sifat observational dan masalah yang diteliti terjadi dengan sendirinya tanpa intervasi dari peneliti. Sampel penelitian adalah mahasiswa FK UNSRAT angkatan 2011 berjumlah 100 orang yang diambil secara acak. Hasil: Hasil penelitian menunjukkan ada hubungan antara lama waktu jeda penggunaan laptop $(r=9,487, p<0,05)$ dan lama waktu mulai merasakan keluhan penglihatan $(r=9,487, p<0,05)$ dengan keluhan penglihatan, sedangkan jenis kelamin $(r=3,841, p>0,05)$, riwayat pemakaian laptop $(r=5,991, p>0,05)$, dan pengguna kacamata $(r=5,991, p>0,05)$ tidak berhubungan secara signifikan dengan keluhan penglihatan.
\end{abstract}

Simpulan: Waktu penggunaan laptop berhubungan secara signifikan dengan keluhan penglihatan. Kata kunci: waktu penggunaan laptop, keluhan penglihatan.

Mata merupakan organ penglihatan yang diciptakan Tuhan dan merupakan salah satu organ vital yang penting nilainya. Dengan menggunakan mata, manusia dapat memperoleh informasi sebanyak $80 \%$ hanya dengan melihat. ${ }^{1}$ Seiring dengan kemajuan perkembangan zaman proses melihat untuk mencari informasi semakin dipermudah dengan teknologi-teknologi yang ada, salah satunya adalah dengan penggunaan komputer deskop dan laptop. Memandang hal tersebut, semakin banyak orang harus bekerja di depan komputer selama berjam-jam tanpa istirahat. Tanpa disadari, bekerja berlama-lama di depan komputer dapat menimbulkan masalah 
kesehatan negatif baik secara fisik maupun mental pada operatornya. Kumpulan gangguan fisik yang menyerang pengguna komputer disebut Computer Vision Syndrome (CVS). Sekitar 88-90\% pengguna komputer mengalami CVS. Kejadian CVS juga dinyatakan mengalami peningkatan dari tahun ke tahun. ${ }^{2}$ National Institute for Occupational Safety and Health (NIOSH) VDT Studies and Information untuk melakukan istirahat selama 15 menit terhadap pemakaian pemakaian komputer selama 2 jam. Hal ini dimaksudkan untuk memotong rantai kelelahan sehingga akan menambah kenyamanan lebih lama bagi pengguna komputer. ${ }^{5}$ Sama halnya dengan komputer, durasi penggunaan laptop lebih dari 2 jam per hari akan menimbulkan keluhan kesehatan. ${ }^{6}$

Bila dilihat dari segi penggunaan, penggunaan laptop semakin menjadi primadona dibandingkan dengan komputer desktop. Hal ini dikarenakan harga laptop yang semakin terjangkau dibandingkan harga komputer deskop. Selain itu juga laptop lebih fleksibel karena mudah dibawa kemana-mana. ${ }^{6}$

Penggunaan laptop lebih diminati dibandingkan dengan penggunaan komputer di Fakutas Kedokteran Universitas Sam Ratulangi, terutama dikalangan mahasiswa. Mengingat penggunaan laptop dapat menimbulkan masalah kesehatan, oleh sebab itu peneliti tertarik untuk meneliti hubungan waktu penggunaan laptop dengan keluhan penglihatan pada mahasiswa Fakultas Kedokteran Universitas Sam Ratulangi.

\section{METODE PENELITIAN}

Penelitian ini bersifat survey analitik dengan menggunakan desain potong lintang (cross sectional) dengan sifat observasional. Populasi dari penelitian ini adalah semua mahasiswa angkatan 2011 Fakultas Kedokteran Universitas Sam Ratulangi Manado sebanyak 587 orang dengan sampel berjumlah 100 orang yang dipilih dengan teknik pengambilan sampel secara acak sederhana (simple random sampling). Cara pengambilan diperoleh melalui kuesioner dengan menggunakan pertanyaan terstruktur dan diolah menggunakan uji Chi Square dengan tingkat signifikan $5 \%(0,005)$.

\section{HASIL PENELITIAN}

\section{Analisis univariat}

\section{Gambaran umum subyek}

Total sampel berjumlah 100 orang, dengan laki-laki sebanyak 36 orang (36\%) dan perempuan sebanyak 64 orang (64\%). Karakteristik umur mahasiswa angkatan 2011 berkisar 18-19 tahun dengan mahasiswa yang berumur 18 tahun sebanyak 50 orang (50\%) dan yang berumur 19 tahun sebanyak 50 orang (50\%).

Pada frekuensi alat bantu penglihatan yang tidak menggunakan kacamata sebanyak 71 orang (71\%) dan yang menggunakan kacamata sebanyak 29 orang (29\%). Dari 29 orang yang menggunakan kacamata didapati bahwa sebanyak 17 orang (58,6\%) yang menggunakan kacamata lensa minus dan 12 orang (41,4\%) yang menggunakan kacamata lensa minus dan silinder, sedangkan yang menggunakan kacamata silinder atau pun kacamata berlensa plus tidak terdapat pada penelitian ini.

\section{Waktu penggunaan laptop}

Lama penggunaan laptop rata-rata dalam sehari yang paling banyak digunakan responden adalah 2-3 jam yaitu sebanyak 41 orang (41\%), kemudian lebih dari 4 jam sebanyak 31 orang (31\%), 1-2 jam sebanyak 24 orang (24\%), dan kurang dari 1 jam sebanyak 4 orang.

Pada penelitian ini untuk waktu jeda saat menggunakan laptop didapatkan responden lebih banyak memberikan jeda waktu saat menggunakan laptop, yaitu sebanyak sebanyak 73 orang (73\%) sedangkan responden yang tidak memberikan jeda saat menggunakan laptop sebanyak 27 orang (27\%). Pada responden yang memberikan waktu jeda saat menggunakan laptop didapatkan responden 
Lama penggunaan laptop rata-rata dalam sehari

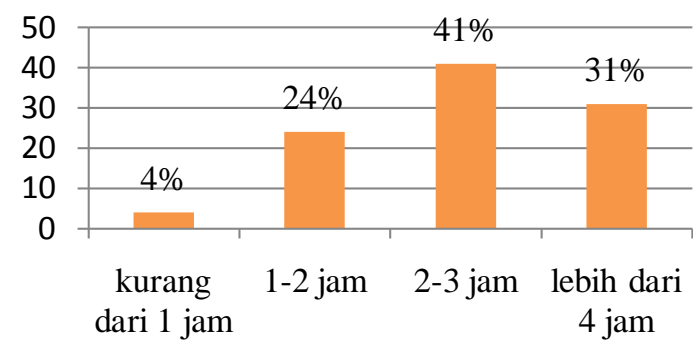

Gambar 2. Distribusi frekuensi lama penggunaan laptop rata-rata dalam sehari.

lebih banyak memberikan waktu jeda 10 15 menit,sebanyak 31 orang (42,5\%), sedangkan responden yang memberikan waktu jeda $1-5$ menit sebanyak 20 orang (27,4\%), responden yang memberikan waktu jeda 15 - 20 menit sebanyak 18 orang $(24,7 \%)$, dan responden yang memberikan waktu jeda 5 - 10 menit menit sebanyak 4 orang (5,5\%).

Sebagian besar responden penelitian, yaitu 76 orang (76\%) mengeluhkan mengalami keluhan penglihatan dan 24 orang (24\%) sama sekali tidak mengalami keluhan penglihatan dilihat dari lamanya waktu penggunaan laptop. Responden mulai merasakan keluhan penglihatan paling banyak adalah pada 2-3 jam saat menggunakan laptop, yaitu sebanyak 27 orang (35,5\%), meskipun tidak ada perbedaan yang terlalu jauh dengan kelompok responden yang mulai merasakan keluhan penglihatan pada 1-2 jam saat menggunakan laptop yaitu sebanyak 25 orang (32,9\%), dan pada lebih dari 4 jam saat menggunakan laptop yaitu sebanyak 18 orang $(23,7 \%)$.

Hasil penelitian ini melaporkan gejala yang paling banyak dikeluhkan oleh responden adalah mata tegang atau lelah (73\%), sedangkan gejala yang paling sedikit yang dikeluhkan adalah sakit kepala (36\%).

\section{Lama waktu jeda}

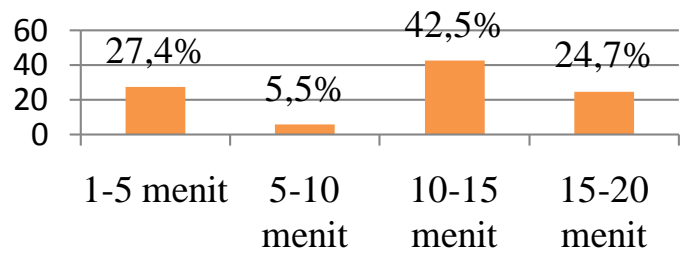

Gambar 3. Distribusi frekuensi lama waktu jeda.

\section{Analisis bivariat}

\section{Hubungan jenis kelamin dengan keluhan}

Hasil analisis bivariat mengenai hubungan antara jenis kelamin dengan keluhan penglihatan didapatkan nilai $p$ untuk mata terasa gatal $(p=0,849)$, mata terasa kering ( $p=0,019)$, mata terasa nyeri $(p=0,324)$, mata tegang atau lelah $(p=$ $0,361)$, mata berair $(p=0,596)$, rasa silau $(p=0,596)$, penglihatan kabur atau berbayang ( $p=0,006)$, dan sakit kepala ( $p$ $=0,086)$ lebih kecil dibanding nilai $\mathrm{r}(r=$ 3,841). Hal tersebut menunjukkan bahwa antara jenis kelamin tidak berhubungan secara signifikan dengan keluhan penglihatan.

Tabel 7. Hubungan antara jenis kelamin dengan keluhan penglihatan

\begin{tabular}{ccccccccc}
\hline \multirow{2}{*}{$\begin{array}{c}\text { Jenis } \\
\text { kelamin }\end{array}$} & Gatal & Kering & Nyeri & $\begin{array}{c}\text { Tegang/ } \\
\text { lelah }\end{array}$ & Berair & Silau & Kabur & $\begin{array}{c}\text { Sakit } \\
\text { kepala }\end{array}$ \\
\cline { 2 - 9 } & 14 & 23 & 12 & 25 & 14 & 14 & 9 & 9 \\
Laki-laki & 14 & 40 & 25 & 48 & 30 & 30 & 34 & 27 \\
\hline Total & 45 & 63 & 37 & 73 & 44 & 44 & 43 & 36 \\
\hline
\end{tabular}


Tabel 8. Hubungan antara pengguna kacamata dan bukan pengguna kacamata dengan keluhan penglihatan

\begin{tabular}{|c|c|c|c|c|c|c|c|c|c|c|c|c|c|c|c|c|}
\hline \multirow{3}{*}{$\begin{array}{c}\text { Pengguna } \\
\text { kecamata } \\
\text { dan } \\
\text { bukan } \\
\text { pengguna } \\
\text { kacamata }\end{array}$} & \multicolumn{16}{|c|}{ Keluhan penglihatan } \\
\hline & \multicolumn{2}{|c|}{ Gatal } & \multicolumn{2}{|c|}{ Kering } & \multicolumn{2}{|c|}{ Nyeri } & \multicolumn{2}{|c|}{$\begin{array}{l}\text { Tegang/ } \\
\text { lelah }\end{array}$} & \multicolumn{2}{|c|}{ Berair } & \multicolumn{2}{|c|}{ Silau } & \multicolumn{2}{|c|}{ Kabur } & \multicolumn{2}{|c|}{$\begin{array}{l}\text { Sakit } \\
\text { kepala }\end{array}$} \\
\hline & $\mathrm{n}$ & $\%$ & $\mathrm{n}$ & $\%$ & $\mathrm{n}$ & $\%$ & $\mathrm{n}$ & $\%$ & $\mathrm{n}$ & $\%$ & $\mathrm{n}$ & $\%$ & $\mathrm{n}$ & $\%$ & $\mathrm{n}$ & $\%$ \\
\hline $\begin{array}{c}\text { Kacamata } \\
\text { lensa } \\
\text { minus }\end{array}$ & 5 & 11,1 & 13 & 20,6 & 7 & 18,9 & 13 & 17,8 & 7 & 15,9 & 7 & 15,9 & 6 & 14,0 & 6 & 16,7 \\
\hline $\begin{array}{l}\text { Kacamata } \\
\text { lensa } \\
\text { minus dan } \\
\text { silinder }\end{array}$ & 4 & 8,9 & 7 & 11,1 & 4 & 10,8 & 7 & 9,6 & 4 & 9,1 & 3 & 6,8 & 6 & 14,0 & 6 & 16,7 \\
\hline $\begin{array}{c}\text { Bukan } \\
\text { pengguna } \\
\text { kacamata }\end{array}$ & 36 & 80,0 & 43 & 68,3 & 26 & 70,3 & 53 & 72,6 & 33 & 75,0 & 34 & 77,3 & 31 & 72,1 & 24 & 66,7 \\
\hline Total & 45 & 100 & 63 & 100 & 37 & 100 & 73 & 100 & 44 & 100 & 44 & 100 & 43 & 100 & 36 & 100 \\
\hline
\end{tabular}

Tabel 9. Hubungan antara riwayat penggunaan laptop dengan keluhan penglihatan

\begin{tabular}{ccccccccc}
\hline \multirow{2}{*}{$\begin{array}{c}\text { Riwayat } \\
\text { penggunaan laptop }\end{array}$} & Gatal & Kering & Nyeri & $\begin{array}{c}\text { Tegang/ } \\
\text { lelah }\end{array}$ & Berair & Silau & Kabur & $\begin{array}{c}\text { Sakit } \\
\text { kepala }\end{array}$ \\
\cline { 2 - 9 } & 0 & 0 & 0 & 0 & 1 & 1 & 0 & 0 \\
\hline 1 tahun & 3 & 8 & 6 & 9 & 5 & 5 & 3 & 3 \\
$1-2$ tahun & 42 & 55 & 31 & 64 & 38 & 38 & 40 & 33 \\
$>2$ tahun & 45 & 63 & 37 & 73 & 44 & 44 & 43 & 36 \\
\hline Total & & & & & & & & \\
\hline
\end{tabular}

Hubungan antara pengguna kacamata dan bukan pengguna kacamata dengan keluhan penglihatan

Hasil analisis bivariat antara pengguna kacamata dan bukan pengguna kacamata dengan keluhan penglihatan didapatkan nilai $p$ untuk mata terasa gatal $(p=3,266)$, mata terasa kering $(p=1,616)$, mata terasa nyeri $(p=0,201)$, mata tegang atau lelah ( $p$ $=1,511)$, mata berair $(\mathrm{p}=0,786)$, rasa silau $(\mathrm{p}=2,249)$, penglihatan kabur atau berbayang ( $\mathrm{p}=0,664)$, dan sakit kepala ( $\mathrm{p}$ $=1,173)$ lebih kecil dibanding nilai $\mathrm{r}(\mathrm{r}=$ 5,991). Hal tersebut menunjukkan bahwa pengguna kacamata dan bukan pengguna kacamata tidak berhubungan secara signifikan dengan keluhan penglihatan.

\section{Hubungan antara riwayat penggunaan laptop dengan keluhan penglihatan}

Hasil analisis bivariat mengenai hubungan antara antara riwayat penggunaan laptop dengan keluhan penglihatan didapatkan nilai $p$ untuk mata terasa gatal ( $p=$ 4,692), mata terasa kering ( $p=2,015)$, mata terasa nyeri $(p=0,804)$, mata tegang atau lelah $(p=3,470)$, mata berair $(p=1,680)$, rasa silau ( $p=1,680)$, penglihatan kabur atau berbayang $(p=3,984)$, dan sakit kepala $(p=2,147)$ lebih kecil dibanding nilai $\mathrm{r}(r=5,991)$. Hal tersebut menunjukkan bahwa riwayat pemakaian laptop tidak berhubungan secara signifikan dengan keluhan penglihatan. 
Tabel 10. Hubungan antara lama penggunaan laptop rata-rata dalam sehari dengan keluhan penglihatan

\begin{tabular}{|c|c|c|c|c|c|c|c|c|}
\hline \multirow[b]{2}{*}{$\begin{array}{c}\text { Lama waktu } \\
\text { jeda }\end{array}$} & \multicolumn{8}{|c|}{ Keluhan penglihatan } \\
\hline & Gatal & Kering & Nyeri & $\begin{array}{l}\text { Tegang/ } \\
\text { lelah }\end{array}$ & Berair & Silau & Kabur & $\begin{array}{c}\text { Sakit } \\
\text { Kepala }\end{array}$ \\
\hline $1-5$ menit & 8 & 17 & 7 & 13 & 6 & 11 & 11 & 8 \\
\hline $5-10$ menit & 3 & 4 & 2 & 4 & 3 & 1 & 2 & 1 \\
\hline $10-15$ menit & 18 & 22 & 14 & 25 & 16 & 12 & 16 & 13 \\
\hline 15 - 20 menit & 7 & 9 & 5 & 11 & 8 & 7 & 5 & 6 \\
\hline $\begin{array}{l}\text { Tidak ada waktu } \\
\text { jeda }\end{array}$ & 9 & 11 & 9 & 20 & 11 & 13 & 9 & 8 \\
\hline Total & 45 & 63 & 37 & 73 & 44 & 44 & 43 & 36 \\
\hline
\end{tabular}

Hubungan antara lama penggunaan laptop rata-rata dalam sehari dengan keluhan penglihatan

Hasil analisis bivariat mengenai hubungan lama waktu jeda penggunaan laptop dengan keluhan penglihatan didapatkan nilai $p$ untuk mata terasa gatal $(p$ $=5,421)$, mata terasa nyeri $(p=2,456)$, mata tegang atau lelah ( $p=6,957)$, mata berair $(p=4,010)$, rasa silau $(p=3,227)$, penglihatan kabur atau berbayang ( $p=$ $5,337)$, dan sakit kepala ( $p=1,309)$ lebih kecil dibandingkan nilai $\mathrm{r}(r=9,487)$, sedangkan nilai $p$ untuk mata terasa kering $(p=13,998)$ lebih besar dibandingkan nilai r. Hal tersebut menunjukkan bahwa hubungan lama waktu jeda penggunaan laptop tidak berhubungan secara signifikan dengan keluhan penglihatan seperti mata terasa gatal, mata terasa nyeri, mata tegang atau lelah, mata berair, rasa silau, penglihatan kabur atau berbayang, dan sakit kepala, namun berhubungan secara secara signifikan dengan keluhan penglihatan mata kering.

\section{Hubungan lama waktu mulai merasakan keluhan penglihatan dan keluhan penglihatan}

Hasil analisis bivariat mengenai lama waktu mulai merasakan keluhan penglihatan dan keluhan penglihatan didapatkan nilai $p$ untuk rasa silau ( $p=6,753)$, dan sakit kepala $(p=3,814)$ lebih kecil dibandingkan nilai $\mathrm{r}(r=9,487)$, sedangkan nilai $p$ untuk mata terasa gatal $(p=17,134)$, mata terasa kering ( $p=12,472)$, mata terasa nyeri $(p=14,938)$, mata tegang atau lelah ( $p=16,996)$, mata berair $(p=20,070)$, dan penglihatan kabur atau berbayang ( $p=$ 15,802) lebih besar dibandingkan nilai $r$. Hal tersebut menunjukkan bahwa hubungan lama waktu mulai merasakan keluhan penglihatan tidak berhubungan

Tabel 11. Hubungan lama waktu mulai merasakan keluhan penglihatan dan keluhan penglihatan

\begin{tabular}{|c|c|c|c|c|c|c|c|c|}
\hline \multirow{2}{*}{$\begin{array}{l}\text { Lama } \\
\text { waktu }\end{array}$} & \multicolumn{8}{|c|}{ Keluhan penglihatan } \\
\hline & Gatal & Kering & Nyeri & $\begin{array}{c}\text { Tegang/ } \\
\text { lelah }\end{array}$ & Berair & Silau & Kabur & $\begin{array}{c}\text { Sakit } \\
\text { Kepala }\end{array}$ \\
\hline$<1 \mathrm{jam}$ & 4 & 6 & 5 & 6 & 6 & 5 & 5 & 3 \\
\hline $1-2$ jam & 17 & 20 & 13 & 21 & 17 & 13 & 14 & 12 \\
\hline $2-3$ jam & 15 & 18 & 11 & 21 & 10 & 12 & 14 & 7 \\
\hline$>4$ jam & 4 & 8 & 5 & 15 & 6 & 7 & 7 & 7 \\
\hline $\begin{array}{c}\text { Tidak ada } \\
\text { keluhan }\end{array}$ & 5 & 11 & 3 & 10 & 5 & 7 & 3 & 7 \\
\hline Total & 45 & 63 & 37 & 73 & 44 & 44 & 43 & 36 \\
\hline
\end{tabular}


secara signifikan dengan keluhan penglihatan seperti, rasa silau dan sakit kepala, namun berhubungan secara secara signifikan dengan keluhan penglihatan mata terasa gatal, mata terasa kering, mata terasa nyeri, mata tegang atau lelah, mata berair, dan penglihatan kabur atau berbayang.

\section{PEMBAHASAN}

\section{Waktu penggunaan laptop}

Penelitian di University of South Carolina mengkategorikan penggunaan komputer menjadi tiga kategori yaitu ringan (kurang dari 2 jam), sedang (2-4 jam), dan berat (lebih dari 4 jam) per hari. Penelitian Taylor (2007), di 16 negara di dunia menunjukkan rata-rata lama penggunaan komputer per harinya adalah sekitar 5 jam. Penelitian Sen et al (2007) menunjukkan hampir setengah dari pengguna komputer menggunakan komputer secara terus-menerus tanpa istirahat lebih dari 2 jam per harinya. Penelitian Hoesin et al (2007) di 16 kota di Indonesia menunjukkan rata-rata penggunaan komputer di Indonesia kurang dari 5 jam per hari. Di Bantul, 7 \% pengguna komputer menggunakan komputer dalam intensitas yang rendah, $3 \%$ dengan intensitas sedang, $83 \%$ dengan intensitas tinggi (Indriawati et al, 2008). Penelitian Dewi et al (2009) di kantor Samsat Palembang menunjukkan 75 $\%$ pekerja menggunakan komputer lebih dari 4 jam. ${ }^{7}$

Sejalan dengan penelitian sebelumnya di Indonesia, pada penelitian ini didapatkan bahwa mahasiswa Fakultas Kedokteran Universitas Sam Ratulangi telah menggunakan laptop paling banyak yaitu lebih dari 2 tahun (85\%) dengan rata-rata dalam sehari adalah 2-3 jam (41\%).

\section{Keluhan penglihatan}

Sering dan lamanya seseorang bekerja dengan komputer, dapat mengakibatkan keluhan serius pada mata. Keluhan yang sering diungkapkan oleh pekerja komputer adalah: (1) kelelahan mata yang merupakan gejala awal, (2) mata terasa kering, (3) mata terasa terbakar, (4) pandangan menjadi kabur, (5) penglihatan ganda, (6) sakit kepala, (7) nyeri pada leher, bahu dan otot punggung. Penelitian Sundari (2011) di Bali menunjukkan orang yang bekerja selama 2 jam dengan terpapar dengan layar monitor akan menyebabkan meningkatnya kelelahan secara umum sebesar 37,29\% dan menurunnya aktifitas kerja sebesar $39,08 \%{ }^{8,14}$

Keluhan yang akan ditimbulkan akibat penggunaan laptop pada mata hampir sama dengan keluhan yang ditimbulkan akibat penggunaan komputer PC. ${ }^{16}$

Pada keluhan penglihatan jenis kelamin perempuan merupakan faktor risiko CVS dimana angka kejadian CVS lebih tinggi pada perempuan meskipun tidak berhubungan secara signifikan Beberapa pendapat yang dapat mendukung hasil penelitian ini diantaranya adalah perbedaan fisiologis antara perempuan dan laki-laki yang menyebabkan perempuan lebih rentan terhadap penyakit dan tingkat stress perempuan yang lebih tinggi daripada laki-laki. Perempuan cenderung lebih teliti dan telaten dalam bekerja sehingga mereka akan benar-benar memusatkan perhatian pada pekerjaan yang dihadapi untuk mengurangi tingkat kesalahan kerja. Tuntutan untuk dapat memusatkan perhatian di depan komputer secara terus-menerus menjadi sumber stressor untuk penglihatan maupun psikologis dan akhirnya menimbulkan keluhankeluhan penglihatan. $^{9}$

Pada penelitian ini keluhan yang paling banyak dikeluhkan adalah mata tegang (73\%) dan mata terasa kering (63\%).

Kelelahan mata adalah ketegangan pada mata dan disebabkan oleh penggunaan indera penglihatan dalam bekerja yang memerlukan kemampuan untuk melihat dalam jangka waktu yang lama yang biasanya disertai dengan kondisi pandangan yang tidak nyaman. Jarak antara layar monitor dan mata yang terlalu dekat dapat menyebabkan mata menjadi tegang, cepat lelah, dan berpontensi mengalami 
keluhan penglihatan. Selain itu juga, mata lelah dapat disebabkan karena tidak mengalihkan pandangan sejauh kurang lebih enam meter selama beberapa detik setiap 30 menit menggunakan laptop. Pengalihan pandangan ini berfungsi untuk merelaksasikan ketegangan yang terjadi pada otot mata. ${ }^{10,11}$

Mata kering atau sindroma dry eye bisa terjadi karena mata terbuka lebar menatap layar monitor terus-menerus. Normalnya frekuensi mengedip seseorang adalah 10-15 kali per menit, akan tetapi karena terbuka lebar menatap layar monitor terus-menerus mengakibatkan frekuensi mengedip berkurang sehingga terjadi penguapan air mata yang berlebihan. Penguapan air mata yang berlebihan ini yang akan mengakibatkan mata menjadi kering. Selain itu juga adapun faktor resiko sindroma dry eye yang mempengaruhi seorang pekerja yang terpapar layar monitor adalah faktor pekerja dan faktor lingkungan. Faktor pekerja antara lain faktor usia, jenis kelamin, kebiasaan membaca, masa kerja dan kelainan refraksi, sedangkan faktor lingkungan kerja meliputi faktor suhu, kelembapan, penerangan, tinggi meja, tinggi kursi, dan jarak mata ke monitor. $^{12-16}$

\section{Hubungan waktu penggunaan laptop dengan keluhan penglihatan}

Penelitian Bhanderi et al. yang melaporkan bahwa angka kejadian CVS lebih tinggi pada pengguna VDT yang bekerja secara terus-menerus dalam sehari. Seorang individu yang bekerja di depan komputer selama lebih dari atau sama dengan 4 jam secara terus-menerus berisiko dua puluh enam kali lipat menderita CVS dibandingkan dengan bekerja di depan komputer selama kurang dari 4 jam secara terusmenerus. ${ }^{9}$

Parwati (2004) menyatakan gejala oftalmikus timbul setelah 2 jam penggunaan komputer secara terus-menerus. Penelitian Hiroko (2007) menunjukkan variasi 1-4 jam penggunaan komputer atas kejadian CVS. Broumand et al (2008) menunjukkan perburukan gejala pada pengguna komputer lebih dari 2 jam per hari. Penelitian Kanitkar et al (2005) dan Amalia et al (2010) menunjukkan CVS dialami pengguna komputer lebih dari 3 jam per hari. Penelitian Fenga et al (2007) menunjukkan mata kering mayoritas dialami pengguna komputer lebih dari 4 jam per hari. Penelitian Nakazawa et al (2002) menunjukkan peningkatan bermakna keluhan CVS pada pekerja pengguna komputer lebih dari 5 jam per hari. Penelitian Hanne et al (1994) dan Shigenori et al (2002) menunjukkan gejala CVS baru akan timbul pada pengguna komputer lebih dari 6 jam. Penelitian Sen et al (2007) menunjukkan gejala CVS umumnya dikeluhkan setelah 3 jam penggunaan komputer secara terusmenerus atau setelah 6 jam penggunaan komputer tidak terus-menerus.

Pada penelitian ini didapatkan responden paling banyak mengunakan laptop rata-rata dalam sehari adalah selama 2-3 jam dan mulai mengeluhkan keluhan CVS antara waktu 2-3 jam dengan keluhan paling banyak mata tegang dan mata kering.

Waktu jeda juga mempengaruhi terjadinya keluhan penglihatan. Pada penelitian ini responden menyediakan waktu jeda yang paling banyak 10-15 menit (42,5\%). Pada penelitian sebelumnya, lama istirahat selama kurang dari 10 menit setelah terpapar layar monitor berisiko dua puluh kali lipat menderita CVS dibandingkan dengan istirahat selama lebih dari atau sama dengan 10 menit. Hal ini sesuai dengan teori dan penelitian sebelumnya oleh Ye et al. yang menyatakan bahwa istirahat selama 10-15 menit setelah penggunaan komputer merupakan faktor protektif terhadap munculnya keluhan CVS sedangkan tidak menyempatkan istirahat merupakan faktor risiko dengan odds ratio sebesar 5,1. Jadi dapat disimpulkan bahwa istirahat adalah satu manuver yang paling tepat untuk mencegah terjadinya gejala CVS akibat lama menggunakan komputer. Akan tetapi masih sedikit penelitian mengenai jam istirahat yang ideal. Perlu diingat pula bahwa interupsi yang terlalu sering akan membawa dampak yang kurang 
efektif terhadap pekerjaan yang sedang dikerjakan. ${ }^{7,9,17}$

\section{SIMPULAN DAN SARAN}

Dari hasil penelitian ini dapat disimpulkan beberapa hal, yaitu: (1) jenis kelamin dan riwayat pemakaian laptop tidak berhubungan secara signifikan dengan keluhan penglihatan, (2) pengguna kacamata dan bukan pengguna kacamata tidak berhubungan secara signifikan dengan keluhan penglihatan, (3) lama waktu jeda penggunaan laptop tidak berhubungan secara signifikan dengan keluhan penglihatan seperti mata terasa gatal, mata terasa nyeri, mata tegang atau lelah, mata berair, rasa silau, penglihatan kabur atau berbayang, dan sakit kepala, namun berhubungan secara secara signifikan dengan keluhan penglihatan mata kering, (4) lama waktu mulai merasakan keluhan penglihatan tidak berhubungan secara signifikan dengan keluhan penglihatan seperti, rasa silau dan sakit kepala, namun berhubungan secara secara signifikan dengan keluhan penglihatan mata terasa gatal, mata terasa kering, mata terasa nyeri, mata tegang atau lelah, mata berair, dan penglihatan kabur atau berbayang.

Saran dari penulis usahakan untuk berhenti sejenak untuk mengistirahatkan mata, istirahat sejenak tapi sering dapat menurunkan tingkat ketidaknyamanan, kemudian mengediplah lebih sering untuk menghindari sindroma mata kering, dan lakukan pemeriksaan kesehatan mata bila dirasakan keluhan yang semakin berat.

\section{UCAPAN TERIMA KASIH}

Penulis berterima kasih kepada DR. dr. J. S. M. Saerang, SpM (K), dr. Herny Poluan, SpM, dan dr. Harry Sumual, SpM selaku penguji I, penguji II, dan penguji III. Tidak lupa pula kepada DR. dr. J. S. M. Saerang, SpM (K) dan dr. Laya M. Rares, SpM selaku pembimbing I dan pembimbing II, serta kepada semua pihak baik secara langsung maupun tidak langsung telah menumbuhkan ide atau gagasan pada penulis.

\section{DAFTAR PUSTAKA}

1. Andriono GA. Kecacatan akibat kecelakaan kerja dan penyakit akibat kerja pada mata [homepage on the Internet]. Nodate [cited 2012 Oct 19]. Available from: http://www.jamsostek.co.id/ content_file/mata.pdf.

2. Citra A. Hubungan lama penggunaan komputer dengan sindroma mata kering [Skripsi]. Medan: USU; 2011.

3. Affandi SA. Sindrom Penglihatan Komputer (Computer Vision Syndrome). Majalah Kedokteran Indonesia [serial online]. 2005; 55(3):297-00. Available from: (http://mki.idionline.org /index.php)

4. Hasibuan FS. Hubungan faktor keturunan, lamanya bekerja jarak dekat, dengan miopia pada mahasiswa FK USU [Skripsi]. Medan: USU; 2009.

5. Mustopo I, Sarimurni. Pengaruh radiasi layar komputer terhadap kemampuan daya akomodasi mata mahasiswa pengguna komputer di Universitas Muhamadiyah Surakarta. Jurnal Penelitian Sains \& Teknologi. 2005;6(2):153-63.

6. Hendra, Octaviani DF. Keluhan Kesehatan akibat penggunaan laptop pada mahasiswa FKM UI [homepage on the Internet]. Available from: http://staff.ui.ac.id/internal/132255817/publ ikasi/KeluhanKesehatanAkibatPenggunaan LaptoppadaMahasiswaFKM.pdf.

7. Zubaidah H. S. T. Pengaruh lama terpapar dan jarak monitor komputer terhadap gejala computer vision syndrome pada pegawai negeri sipil di kantor pemerintahan kota Medan [Tesis]. Medan: USU; 2012.

8. Sundari Nelly Komang. Keluhan subjektif pada operator komputer di unit pelaksana teknis-pengembangan seni dan teknologi keramik dan porselin Bali. Jurnal Ilmiah Teknik Industri [serial online]. 2011;10(2):88-94. Available from: http://publikasiilmiah.ums.ac.id/bitstream/h andle/123456789/1446/JITI-10-12Sundari-OK.pdf?sequence $=1$ )

9. Azkadina A. Hubungan antara faktor risiko individual dan komputer terhadap kejadian computer vision syndrome [Skripsi]. Semarang : UNDIP ; 2012. 
10. Maryam S. Faktor-faktor yang berhubungan dengan keluhan kelelahan mata pada pengguna komputer di bagian outbound call gedung graha telkom bsd (bumi serpong damai) Tangerang tahun 2011 [Skripsi]. Jakarta: Universitas Islam Negeri Syarif Hidayatullah Jakarta; 2011.

11. Puspitasari A. Hubungan antara perilaku penggunaan laptop dan keluhan kesehatan akobat penggunaan laptop pada mahasiswa sarjana reluger [Skripsi]. Jakarta: Fakultas Ilmu Komputer Universitas Indonesia; 2012.

12. Roestijiwati N. Hubungan penggunaan visual display terminal (VDT), faktor pekerja dan lingkungan kerja dengan sindroma dry eye. Jurnal Kedokteran YARSI [serial online]. 2005;13(2):205-17. Available from: http://www.yarsi.ac.id/daf tar-jurnal-yarsi/92-fakultas-kedokteranyarsi/403-hubungan-penggunaan-visualdisplay-terminal-(vdt)--faktor-pekerja-danlingkungan-k.html.

13. Wimalasundera S. Computer vision syndrome. Galle medical journal [serial online]. 2006;11(1):25-9. Available from: (http://www.sljol.info/index.php/GMJ/artic le/view/1115)

14. Mujaddidi HRA. 2012. Analisis faktor- faktor terhadap kejadian computer vision syndrome (CVS) pada pekerja layout editor di CV. "X" Tembalang Kota Semarang. Jurnal Kesehatan Masyarakat [serial online]. 2012;1(2) :731-37. Available from: (http://ejournals1.undip.ac.id/index.php/jk $\mathrm{m})$

15. Rosenfield M. Computer vision syndrome: a review of ocular causes and potential treatments. The Journal of College of Optometrist. 2011. 31(5):502-15. Available from: (http://onlinelibrary.wiley.com/ doi/10.1111/j.14751313.2011.00834.x/full)

16. Satriadi I. Dampak penggunaan laptop yang mengakibatkan gangguan kesehatan pada manusia. Jurnal Politeknik Negeri Sriwijaya [serial online]. 2009;1(2). Available from: (http://jurnal.polsri.ac.id/ index.php/mi/article/view/40)

17. Rahman ZA. Pengguna Komputer: Faktor Terkait demografi dan Komputer yang mempengaruhi Pengguna Mendapatkan Computer Vision Syndrome. International Journal of Business, Humaniora dan Teknologi [serial online]. 2011;1(2). Available from: (http://www.ijbhtnet.com/ journals/Vol_1_No_2_September_2011/11. pdf) 